\title{
JENIS-JENIS SEMUT ARBOREAL (HYMENOPTERA: FORMICIDAE) DI KAWASAN KAMPUS UNIVERSITAS TANJUNGPURA DENGAN TIGA METODE KOLEKSI
}

\author{
Melvy Indrianasari ${ }^{1^{*}}$, Kustiati $^{1}$, Firman Saputra $^{1}$ \\ ${ }^{1}$ Program Studi Biologi, Fakultas Matematika dan Ilmu Pengetahuan Alam, Universitas Tanjungpura \\ J1. Prof. Dr. H. Hadari Nawawi, Pontianak, Kalimantan Barat \\ *Email korespondensi: melvyindrianasari@gmail.com
}

\begin{abstract}
Ants as insects occupy various habitats and ecological niches. Universitas Tanjungpura is an area with variable vegetation physiognomies that has the potential to have a lot of ant microhabitat. This study aims to determine the most effective method for collecting arboreal ants (Hymenoptera: Formicidae) found in the campus area of Universitas Tanjungpura. The study was conducted from August 2018 to February 2019 at ten locations based on their environmental condition. Ants were collected in three different methods: hand collecting, bait traps, and yellow pan traps. There were 39 species of Formicidae collected from all locations. These results were obtained by hand collecting ( 32 species), bait traps (32 species), and yellow pan traps (4 species). Hand collecting and bait traps are the most effective method for collecting arboreal ants in Universitas Tanjungpura.
\end{abstract}

Keywords: arboreal ants, bait trap, hand collecting, Universitas Tanjungpura, yellow pan trap

\section{PENDAHULUAN}

Semut sebagai serangga anggota Famili Formicidae menempati berbagai relung ekologi dan memanfaatkan banyak sumber makanan yang berbeda baik sebagai herbivora, predator, atau scavenger (pemakan bangkai) (Schultz, 2000). Spesies semut memiliki habitat dan biologi berbeda antara satu dan lainnya. Perbedaan ini menyebabkan banyaknya metode dalam pengoleksian sampel semut di lapangan.

Semut arboreal merupakan tipe semut yang memiliki aktivitas sebagian besar di pohon. Beberapa faktor abiotik dan biotik mempengaruhi komunitas semut arboreal, misalnya distribusi tempat bersarang dan sumber makanan seperti nektar ekstrafloral dan simbion serangga (Blüthgen \& Fielder, 2004). Pola yang diamati di antara hutan tropis seringkali tidak sesuai, kemungkinan karena skala pengambilan sampel yang terbatas dan perbedaan metodologi antara studi (Basset et al. 2003).

Teknik pengoleksian disesuaikan dengan tujuan penelitian (Hashimoto \& Rahman, 2003). Pengoleksian semut dengan pengambilan satu sarang utuh yang berisi semua kasta (larva, pekerja, prajurit, dan ratu serta pejantan) dilakukan untuk studi taksonomi. Sedangkan untuk studi ekologi, faktor yang paling penting adalah mengumpulkan sampel yang dapat diidentifikasi sebanyak mungkin dari berbagai spesies yang ada.
Metode koleksi dapat dilakukan secara aktif maupun pasif. Pengambilan aktif melibatkan pencarian serangga langsung pada lingkungan dan cenderung lebih spesifik terhadap serangga yang diinginkan. Pengumpulan pasif melibatkan pemasangan perangkap, pancingan, dan jebakan tergantung pada aktivitas serangga itu sendiri (Gullan \& Cranston, 2010).

Universitas Tanjungpura adalah daerah dengan fisiognomi vegetasi yang bervariasi dan berpotensi memiliki banyak mikrohabitat semut. Aktivitas dan jenis semut arboreal di kawasan kampus Universitas Tanjungpura perlu diketahui untuk menentukan lokasi digunakan. Perbedaan prilaku antara spesies semut menyebabkan perlunya dilakukan penelitian mengenai metode pengoleksian semut arboreal yang ditemukan.

\section{METODE PENELITIAN}

\section{Waktu dan Tempat Penelitian}

Penelitian ini berlangsung selama 6 bulan, mulai dari Agustus 2018 hingga Februari 2019. Pengambilan sampel dilakukan di Universitas Tanjungpura, Kalimantan Barat. Identifikasi dan pengolahan data dilaksanakan di Laboraturium Biologi dan Zoologi, Jurusan Biologi, Fakultas Matematika dan Ilmu Pengetahuan Alam, Universitas Tanjungpura, Pontianak. 


\section{Deskripsi Lokasi Penelitian}

Universitas Tanjungpura secara administratif terletak di Jl. Prof. Dr. H. Hadari Nawawi, Kelurahan Bansir Laut, Kecamatan Pontianak Tenggara, Kalimantan Barat. Pemanfaatan lahan di Universitas Tanjungpura digunakan sebagai Ruang Terbuka Hijau (RTH) Kampus dan Kawasan Administrasi dan Pembelajaran (KWAP) Kampus (Gambar 1).

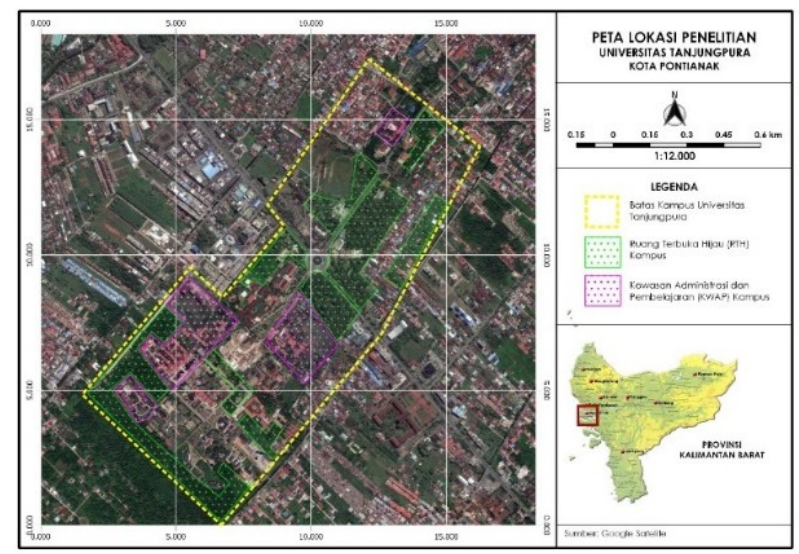

Gambar 1. Peta lokasi Universitas Tanjungpura

Luas wilayah Universitas Tanjungpura $\pm 216 \mathrm{Ha}$, adapun batas-batas wilayah Untan berdasarkan data Bagian Umum Universitas Tanjungpura (2016) adalah sebagai berikut:

a. Utara : berbatasan dengan Jalan Imam Bonjol Kelurahan Bangka Belitung;

b. Selatan : berbatasan dengan Kelurahan Bansir Darat;

c. Barat : berbatasan dengan Kelurahan Benua Melayu Darat dan Kelurahan Parit Tokaya Kecamatan Pontianak Selatan;

d. Timur : berbatasan dengan Kelurahan Bangka Belitung Laut.

Keadaan iklim di Universitas Tanjungpura Kota Pontianak menurut data BMKG Provinsi Kalimantan Barat tahun 2000-2015 (BPS Provinsi Kalbar, 2016) termasuk kedalam iklim tropis. Curah hujan antara 2.547-3.666 mm/tahun dengan rata-rata curah hujan $3128 \mathrm{~mm} /$ tahun. Suhu udara rata-rata $27,9^{\circ}$ Celcius dan kelembaban udara ratarata $80,8 \%$.

\section{Alat dan Bahan}

Alat-alat yang digunakan pada penelitian ini adalah yellow pan, botol spesimen, kapur ajaib, wadah plastic, termohigrometer, kamera, mikroskop stereo Labomed, plastik bening, plastik klip, gabus, mikrometer, jarum pentul, selotip, gunting, tali dan alat tulis. Sedangkan bahan yang digunakan pada penelitian ini ialah alkohol $70 \%$, larutan surfaktan, pepaya dan ikan gembung. Pepaya dipreparasi dengan cara diblender sampai halus sedangkan ikan gembung di potong-potong berbentuk dadu dengan ukuran $1 \mathrm{~cm}^{3}$.

\section{Prosedur Kerja}

\section{Penentuan lokasi sampling}

Penentuan lokasi sampling berdasarkan purposive random sampling. Purposive random sampling merupakan teknik pengambilan sampel dengan memperhatikan pertimbangan-pertimbangan yang dibuat oleh peneliti (Hadi, 2004). Lokasi sampling dibagi menjadi 10 stasiun berdasarkan perbedaan rona lingkungan. Lokasi pengambilan sampel antara lain: Fakultas Matematika dan Ilmu Pengetahuan Alam, Taman Rektorat, Fakultas Teknik, Taman Fakultas Teknik, Taman Digulis, Kawasan Auditorium - Lapangan Bola, Fakultas Kehutanan I, Kawasan Gambut, Hutan Fakultas Keguruan dan Ilmu Pendidikan - Kedokteran, dan Arboretum - Fakultas Pertanian

\section{Pengukuran Parameter Lingkungan}

Parameter lingkungan yang diamati adalah kelembaban udara, suhu udara, keadaan cuaca, dan vegetasi lokasi. Termohigrometer digunakan untuk pengukuran kelembaban dan suhu udara. Keadaan cuaca dan vegetasi dicatat sesuai pada saat pengamatan.

\section{Pengambilan Sampel}

Pengambilan sampel dilakukan dengan tiga metode yaitu hand collecting (Hashimoto \& Rahman, 2003), bait trap (Longino \& Colwell, 1997) dan yellow pan trap (Haneda et al., 2013). Setiap metode memiliki kekurangan dan kelebihan. Cara kerja pengambilan sampel adalah sebagai berikut.

\section{a. Hand collecting}

Pengambilan sampel langsung menggunakan tangan. Semut yang telah diperoleh dimasukan ke dalam plastik klip dan dipindahkan ke botol vial berisi alkohol 70\%. Waktu, lokasi, dan jenis pohon ditemukannya sampel juga dicatat.

\section{b. Bait trap}

Bait trap yang digunakan yaitu menggunakan wadah plastik dengan umpan berupa ikan gembung dan pepaya (Gambar 2). Penggunaan ikan gembung betujuan untuk menangkap semut karnivora, sedangkan pepaya digunakan untuk menangkap semut herbivora. Kapur ajaib digoreskan di dinding wadah plastik. Penggunaan kapur ajaib bertujuan untuk membunuh semut yang terperangkap karena 
tidak memiliki aroma dan bersifat racun kontak. Bait trap digantung pada batang pohon setinggi dada ( $\pm 1,30$ meter). Wadah dipasang pada pukul 07.00 WIB dibiarkan di pohon selama 1x24 jam. Pengoleksian sampel dilakukan pada pukul 16.00 WIB dan keesokan harinya pukul 07.00 WIB. Sampel yang telah diperoleh dimasukan ke dalam plastik klip untuk sementara dan selanjutnya dipindahkan ke botol vial berisi alkohol $70 \%$.

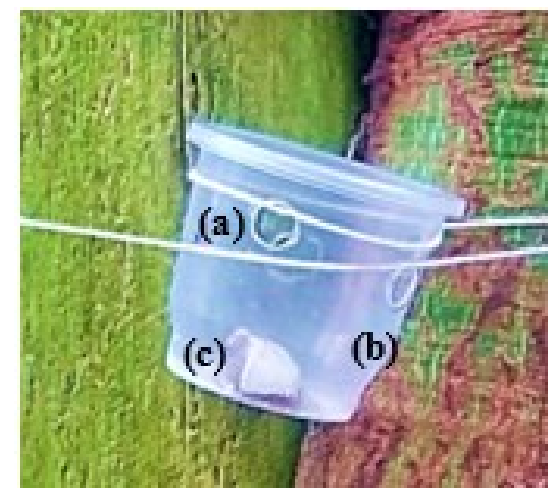

Gambar 2. Bait trap

Keterangan: (a) Lubang masuk semut, (b) kapur ajaib, dan (c) umpan

\section{c. Yellow pan trap}

Metode ini digunakan untuk menjebak semut pada permukaan tanah serta semut yang tertarik dengan warna kuning. Yellow pan trap yang digunakan berupa piring mika bulat berwarna kuning dengan diameter $18 \mathrm{~cm}$. Yellow pan trap diletakkan di permukaan tanah dan di bawah pohon dan diisi dengan larutan surfaktan atau larutan sabun (Gambar 3). Yellow pan trap dipasang dari pukul 07.00 WIB selama 2x24 jam. Sampel yang diperoleh dimasukan ke dalam botol vial berisi alkohol $70 \%$. Pencatatan juga dilakukan terhadap lokasi ditemukannya sampel.

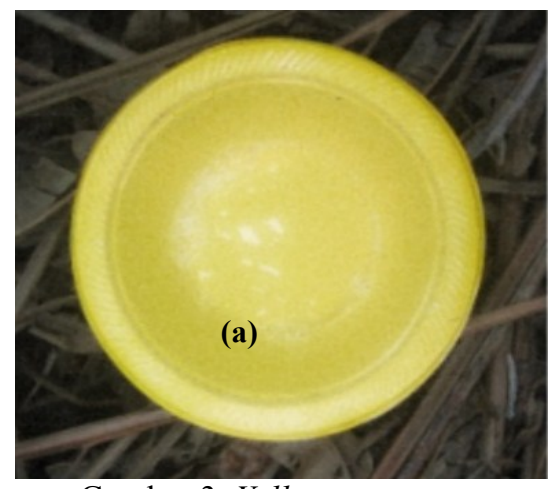

Gambar 3. Yellow pan trap

Keterangan: (a) larutan surfaktan

\section{Identifikasi Semut}

Semut yang diperoleh diidentifikasi berdasarkan perbedaa karakter morfologi. Identifikasi dilakukan di Laboratorium Biologi dan Zoologi, Jurusan Biologi, Fakultas Matematika dan Ilmu Pengetahuan Alam, Universitas Tanjungpura, Pontianak. Proses identifikasi dilakukan dengan menggunakan literatur dari Hashimoto \& Rahman (2003), Hosoishi \& Ogata (2016), Hosoishi \& Ogata (2009), Xu (2001), Cole \& Jones (1948), Clouse (2007), Kohout (2005), Xu \& Zhou (2015), Bolton (2007), Bharti \& Kumar (2012), Ward (2001), Heterick (2003), LaPolla \& Fisher (2014), dan Heterick \& Shattuck (2011).

\section{Identifikasi Tumbuhan}

Identifikasi dilakukan dengan melihat karakteristik secara morfologi tumbuhan yang ditemukan. Bagian tumbuhan yang diamati meliputi daun, batang, bunga, dan buah. Literatur yang dijadikan sebagai rujukan identifikasi yaitu Soepadmo \& Wong (1995).

\section{HASIL DAN PEMBAHASAN}

\section{Hasil}

Semut yang berhasil diperoleh terdiri dari 39 spesies (Tabel 1). Jumlah spesies yang diperoleh secara hand collecting 32 spesies, bait trap 32 spesies, dan yellow pan trap sebanyak empat spesies. Sebagian spesies semut yang sama ternyata ditemukan pada metode pengambilan sampel yang lain. Selain itu, beberapa spesies semut hanya ditemukan pada satu metode pengambilan sampel tertentu (Gambar 4).

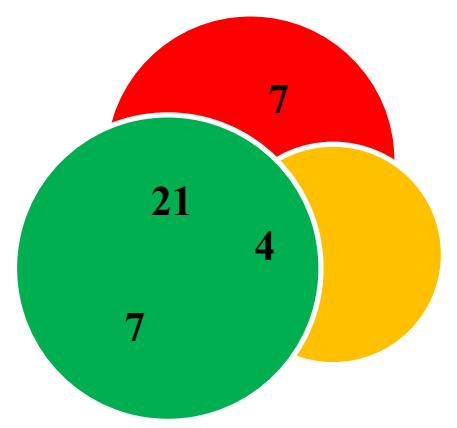

Gambar 4. Perbandingan jumlah spesies Formicidae yang ditemukan di Kawasan Kampus Universitas Tanjungpura Pontianak.

Keterangan:

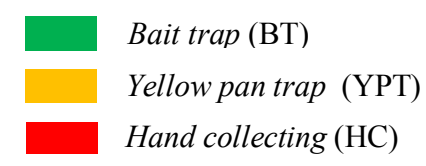


Pengukuran parameter lingkungan di kawasan kampus Universitas Tanjungpura Pontianak dilakukan pada pagi dan sore hari saat pengambilan sampel. Suhu di kawasan kampus Universitas Tanjungpura Pontianak berkisar $22-27{ }^{\circ} \mathrm{C}$ pada pagi hari dan $25-30{ }^{\circ} \mathrm{C}$ pada sore hari. Kelembaban relatif udara pada waktu pagi hari berkisar 89-100 \%, sedangkan pada sore hari berkisar 74$94 \%$. Cuaca pada pagi hari umumnya cerah dan pada sore hari umumnya hujan (Tabel 2).

Tabel 1. Jenis semut yang diperoleh pada masingmasing perangkap

\begin{tabular}{|c|c|c|c|c|}
\hline & \multirow{2}{*}{ Spesies } & \multicolumn{3}{|c|}{ Metode Koleksi } \\
\hline & & HC & BT & YPT \\
\hline & Dolichoderus thoracicus & + & + & + \\
\hline & Iridomyrmex anceps & + & + & - \\
\hline & Tapinoma andamanense & + & - & - \\
\hline & T. melanocephalum & + & + & + \\
\hline & Technomyrmex butteli & + & + & + \\
\hline & T. confexifrons & + & + & - \\
\hline & Anoplolepis gracilipes & + & + & - \\
\hline & Camponotus subtilis & + & + & - \\
\hline & C. nutans & + & - & - \\
\hline & C. reticulatus & + & + & - \\
\hline & Echinopla vermiculata & + & - & - \\
\hline & Nylanderia birmani & + & + & - \\
\hline & N. bourbonica & - & + & - \\
\hline & N. clandestina & + & + & - \\
\hline & N. vaga & - & + & - \\
\hline & N. vividula & + & - & - \\
\hline & Polyrhachis sp. & + & + & - \\
\hline & P. arcuata & - & + & - \\
\hline & P. armata & + & + & - \\
\hline & Paratrechina longicornis & + & + & + \\
\hline & Oecophylla smaragdina & + & + & - \\
\hline & Aphaenogaster weigoldi & + & + & - \\
\hline & Crematogaster sewardi & + & + & - \\
\hline & C. fritzi & - & + & - \\
\hline & C. ampullaris & + & + & - \\
\hline & C. brunnea & + & + & - \\
\hline & C. celebensis & + & + & - \\
\hline & C. phillipinensis & + & - & - \\
\hline & C. sundaladensis & - & + & - \\
\hline & Monomorium floricola & + & + & - \\
\hline & Pheidole parva & + & - & - \\
\hline & Proatta butteli & + & - & - \\
\hline & Tetramorium bicarinatum & + & + & - \\
\hline & T. lanuginosum & + & + & - \\
\hline & T. pacificum & - & + & - \\
\hline & Diacamma rugosum & + & + & - \\
\hline & Tetraponera nodosa & - & + & - \\
\hline & T. allaborans & + & + & - \\
\hline & T. bita & + & + & - \\
\hline$\sum$ & 39 spesies & 32 & 32 & 4 \\
\hline
\end{tabular}

\section{Pembahasan}

Sampel yang diperoleh sebagian besar menggunakan metode hand collecting sebesar $82 \%$ dari 39 spesies (32 spesies) dan bait trap sebesar 82\% (32 spesies), namun tidak banyak ditemukan pada metode yellow pan trap (empat spesies). Diantara 32 spesies diperoleh secara (hand collecting), dengan 25 spesies diantaranya juga terperangkap pada bait trap dan yellow pan trap. Berdasarkan jumlah spesies yang ditemukan, maka hand collecting merupakan metode yang paling efektif dalam pengambilan sampel semut.

Tabel 2. Parameter lingkungan di Kawasan Kampus Universitas Tanjungpura Pontianak

\begin{tabular}{|c|c|c|c|c|c|c|}
\hline \multirow{3}{*}{ Stasiun } & \multicolumn{6}{|c|}{ Faktor Lingkungan } \\
\hline & \multicolumn{2}{|c|}{ Cuaca } & \multicolumn{2}{|c|}{$\begin{array}{l}\text { Suhu udara } \\
\qquad\left({ }^{\circ} \mathrm{C}\right)\end{array}$} & \multicolumn{2}{|c|}{$\begin{array}{c}\text { Kelembaba } \\
\text { n Udara } \\
(\%)\end{array}$} \\
\hline & Pagi & Sore & Pagi & Sore & Pagi & Sore \\
\hline I & Berkabut & Berkabut & 24 & 27 & 94.5 & 74 \\
\hline II & $\begin{array}{l}\text { Mendung } \\
\text { berkabut }\end{array}$ & Hujan & 24 & 25 & 91.5 & 94 \\
\hline III & Mendung & Hujan & 24 & 25 & 91.5 & 91.5 \\
\hline IV & Mendung & Hujan & 23 & 25 & 94 & 94 \\
\hline $\mathrm{V}$ & Cerah & Hujan & 26 & 30 & 91.5 & 74 \\
\hline VI & Cerah & Hujan & 26 & 30 & 91.5 & 74 \\
\hline VII & Cerah & Hujan & 26 & 30 & 91.5 & 74 \\
\hline VIII & Cerah & Hujan & 26 & 30 & 91.5 & 74 \\
\hline IX & Hujan & Cerah & 22 & 26 & 97 & 94 \\
\hline $\mathrm{X}$ & Cerah & Cerah & 25 & 28 & 95 & 80 \\
\hline
\end{tabular}

Pengambilan sampel dengan hand collecting kurang sensitif terhadap perubahan cuaca jika dibandingkan dengan bait trap, karena semut masih dapat ditemukan dan dikoleksi pada keadaan dingin dan lembab (Gotelli et al., 2010). Hand collecting dan pemasangan bait trap dilakukan pada batang pohon setinggi dada $( \pm 1,30$ meter) karena diduga pada bagian tumbuhan tersebut semut arboreal akan lebih mudah ditemukan. Hal ini didukung oleh Longino dan Colwell (1997) yang menyatakan bahwa semut arboreal maupun terestrial akan mencari makan di bagian batang pohon yang rendah. Metode yellow pan trap merupakan metode yang kurang efektif karena metode ini bertujuan untuk menjebak serangga terbang, sehingga diharapkan semut yang terjebak berasal dari kasta semut reproduktif (bersayap).

Berdasarkan preferensi pakan semut terhadap jenis umpan, semut dibagi menjadi tiga kelompok, yaitu: semut yang hanya tertarik pada karbohidrat (umpan pepaya), semut yang hanya tertarik pada protein (umpan ikan), dan semut yang tertarik pada keduanya. Jumlah spesies untuk ketiga kelompok tersebut berturut-turut adalah 14 spesies, tiga spesies, dan 15 spesies. Sebanyak tujuh spesies belum diketahui preferensi pakannya karena spesies tersebut tidak ditemukan pada bait trap yang digunakan. Namun, berdasarkan literatur, seluruh spesies yang ditemukan pada penelitian ini bersifat omnivora (Hunter, 2009; García-Martínez et al., 2015). Hunter (2009) menyatakan bahwa semut merupakan pemakan 
jaringan hewan, eksudat tumbuhan, biji, dan honeydew yang dihasilkan oleh serangga herbivora. Berbagai faktor dapat meningkatkan konsumsi pakan seperti reproduksi, pertumbuhan dan perkembangan (Dam et al., 1994), keterbatasan nutrisi (Denno \& Fagan, 2003), pertahanan tanaman (Agrawal et al., 1999), dan kompetisi (Brabrand, 1985). Pola diet semut bervariasi antara setiap habitat karena ketersediaan sumber makanan yang berbeda.

Perbedaan dalam ketertarikan terhadap makanan dapat disebabkan oleh perubahan lingkungan dan kepadatan makanan (Herbers \& Choiniere, 1996). Berdasarkan penelitian ini, semut yang ditemukan lebih banyak tertarik pada umpan pepaya dan ikan. Koloni semut tersebut diperkirakan memiliki preferensi makan campuran (protein dan karbohidrat). Jika kedua senyawa ini membatasi pertumbuhan suatu koloni, meningkatkan pasokan suatu senyawa akan meningkatkan permintaan akan senyawa lainnya, sehingga permintaan terhadap protein dan karbohidrat seimbang. Clay et al. (2017) berpendapat bahwa kolimitasi (kedua elemen sama-sama membatasi) rsebut harus menghasilkan permintaan gula yang lebih tinggi di padang rumput dengan jumlah mangsa dan nekromassa yang lebih banyak. Sumber karbohidrat di alam diperkirakan lebih sediki pada saat pengambilan sampel, sehingga semut cenderung lebih menyukai karbohidrat. Produksi nektar (kerbohidrat) yang rendah pada suatu lingkungan menyebabkan perubahan preferensi pakan semut. Ketertarikan semut yang lebih tinggi terhadap karbohidrat kemungkinan dipengaruhi hujan saat pengambilan sampel. Curah hujan berpotensi melarutkan nektar (Eisikowitch \& Woodell, 1975) dan nektar encer telah terbukti menghambat penyerbuk dari suatu tumbuhan (Cnaani et al., 2006).

Semut ditemukan dari 25 famili tumbuhan di kawasan kampus Universitas Tanjungpura. Jumlah semut yang ditemukan pada tumbuhan jambu (Myrtaceae) sebanyak 12 spesies. Spesies yang ditemukan antara lain Anoplolepis gracillipes, Camponotus reticulatus, Dolichoderus thoracicus, Iridomyrmex anceps, Oecophylla smaragdina, Paratrechina longicornis, Polyrhachis sp., Tapinoma melanocephalum, Technomyrmex convexifrons, Tetraponera allaborans, dan Tetraponera bita. Keberadaan semut pada suatu tumbuhan dipengaruhi sumber makanan yang tersedia pada tumbuhan tersebut. Nektar merupakan cairan bernutrisi tinggi yang menjadi salah sumber makanan semut. Blüthgen dan Fielder (2004) menyatakan bahwa jumlah semut yang mencari makan di kanopi sebanding dengan jumlah sumber nektar. Myrtaceae merupakan kelompok tumbuhan berkayu yang tersebar hampir di seluruh lokasi pengambilan sampel. Jumlah nektar yang diproduksi oleh Myrtaceae diperkirakan cukup tinggi sehingga mampu menginduksi kehadiran berbagai spesies semut pada tumbuhan tersebut. Fleming dan Kress (2013) menyatakan bahwa Myrtaceae merupakan kelompok tumbuhan yang menjadi sumber nektar yang berlimpah. Myrtaceae memiliki nektar dengan kandungan dihydroxyacetone (DHA), glukosa, fruktosa, dan sukrosa (Clearwater et al., 2018). Sukrosa lebih disukai oleh semut. Daya tarik umpan sukrosa meningkat seiring dengan peningkatan konsentrasi. Semut lebih suka larutan gula yang mengandung campuran asam amino daripada larutan gula murni. Preferensi jenis asam amino dalam larutan gula berbeda antara spesies semut (Blüthgen \& Fielder, 2004). Selain produksi nektar yang tinggi, naungan dan Volatile Organic Compound (VOC) pada tumbuhan juga memengaruhi keberadaan semut (Kost et al., 2011).

Faktor lingkungan yang diukur pada saat penelitian yaitu kelembaban relatif dan suhu udara. Kelembaban udara pada waktu pagi hari berkisar 89-100 \%, dan pada sore hari berkisar 74$94 \%$. Selain dipengaruhi oleh keadaan morfologi, aktivitas semut juga dapat dipengaruhi oleh keadaan lingkungan (Frouz \& Jílková, 2008; North, 1991). Preferensi semut terhadap kelembaban berbeda antara tiap spesies (North, 1991). Anakan semut memiliki preferensi terhadap tingkat kelembaban yang tinggi. Kelembaban tinggi dapat mencegah kehilangan air melalui kutikula yang masih lunak (Potts et al., 1984). Semut yang ditemukan pada lokasi penelitian berasal dari kasta semut pekerja. Kelembaban tidak berpengaruh signifikan terhadap aktivitas semut pekerja (North, 1991).

Suhu udara pada pagi hari berkisar antara 22-27 ${ }^{\circ} \mathrm{C}$ dan sore hari berkisar $25-30{ }^{\circ} \mathrm{C}$. Jumar (2000) menyatakan bahwa serangga merupakan organisme poikilotermis. Semut dapat menyesuaikan perilakunya terhadap suhu lingkungan (Hurlbert et al., 2008). Puncak aktivitas semut terjadi pada kisaran suhu optimal dan menurun setelahnya (Azcárate \& Peco, 2007). Suhu tinggi meningkatkan kecepatan transpirasi pada semut pekerja (North, 1991). Sebagian besar spesies semut mencari makan pada suhu permukaan antara $10{ }^{\circ} \mathrm{C}$ dan $45{ }^{\circ} \mathrm{C}$ (Hölldobler \& Wilson, 1998). Semut yang ditemukan pada pagi hari sebanyak 20 dan sore hari sebanyak empat spesies. Respon perilaku semut terhadap perubahan suhu adalah beralih dari aktivitas diurnal ke nokturnal (Heatwole \& Muir, 1989). 


\section{DAFTAR PUSTAKA}

Agosti, D \& Johnson, N, 2005, 'AntBase', diakses 2 Februari 2018, <http://antbase.org/>

Agrawal, AA, Kobayashi, C \& Thaler, JS, 1999, 'Influence of Prey Availability and Induced Host-plant Resistance on Omnivory by Western Flower Thrips', Ecology, vol. 80, no. 2, hal. $518-523$

Azcárate, MF \& Peco, B， 2007, 'Harvester Ants (Messor barbarus) as Disturbance Agents in Mediterranean Grasslands', Journal of Vegetation Science, vol. 18, no. 1, hal. 103

Basset, Y, Hammond, P, Barrios, H, Holloway, J \& Miller, S, 2003, 'Vertical Stratification of Arthropod Assemblages' in Arthropods of tropical forests: spatio-temporal dynamics and resource use in the canopy, Cambridge University Press, Cambridge.

Borror, DJ, Triplehorn, CA, \& Johnson, N, 1992, Pengenalan Pelajaran Serangga, Gadjah Mada University Press, Yogyakarta

Bharti, H \& Kumar, R, 2012, 'Taxonomic Studies on Genus Tetramorium Mayr (Hymenoptera, Formicidae) with Report of Two New Species and Three New Records Including a Tramp Species from India With a Revised Key', ZooKeys, vol. 207, no. 207, hal. 11-35

Blüthgen, N \& Fiedler, K, 2004, 'Preferences for Sugars and Amino Acids and Their Conditionality in a Diverse Nectar-feeding Ant Community', Journal of Animal Ecology, vol. 73 , no. 1 , hal. $155-166$

Bolton, B, 2007, 'Taxonomy of the Dolichoderine Ant Genus Technomyrmex Mayr (Hymenoptera: Formicidae) based on the Worker Caste', Contributions of the American Entomological Institute, vol. 35, no. 1, hal. 1-149

BPS Provinsi Kalimantan Barat, 2016, Jumlah Curah Hujan dan Jumlah Hari Hujan di Stasiun Pengamatan BMKG, 2000-2015, diakses 20 Maret 2018,< http://kalbar.bps.go.id/>

Brabrand, Å, 1985, 'Food of Roach (Rutilus rutilus) and Ide (Leusiscus idus): Significance of Diet Shift for Interspecific Competition in Omnivorous Fishes', Oecologia, vol. 66, no. 4, hal. $461-467$

California Academy Of Sciences 2019, 'AntWeb', diakses 15 Agustus 2019, <https://www.antweb. org/>

Clay, NA, Lehrter, RJ \& Kaspari, M, 2017, 'Towards a Geography of Omnivory: Omnivores Increase Carnivory when Sodium is Limiting', Journal of Animal Ecology, vol. 86, no. 6, hal. 1523-1531
Clearwater, MJ, Revell, M, Noe, S \& Manley-Harris, M, 2018, 'Influence of Genotype, Floral Stage, and Water Stress on Floral Nectar Yield and Composition of Mānuka (Leptospermum scoparium)', Annals of Botany, vol. 121, no. 3, hal. $501-512$

Clouse, R, 2007, 'The Ants of Micronesia (Hymenoptera: Formicidae)', Micronesica J. Univ. Guam, vol. 39, no. 2, hal. 171-295

Cnaani, J, Thomson, JD \& Papaj, DR, 2006, 'Flower Choice and Learning in Foraging Bumblebees: Effects of Variation in Nectar Volume and Concentration', Ethology, vol. 112, hal. 278-285

Cole, A \& Jones, J, 1948, 'Study of the Weaver Ant, A Study Oecophylla smaragdina', American Midland Naturalist, vol. 39, no. 3, hal. 641-651

Dam, HG, Peterson, WT \& Bellantoni, DC, 1994, 'Seasonal Feeding and Fecundity of the Clanoid Copepod Acartia tonsa in Long Island Sound: is Omnivory Important to Egg Production?', Hydrobiologia, vol. 292-293, no. 1, hal. 191199

Denno, RF \& Fagan, WF, 2003, 'Might Nitrogen Limitation Promote Omnivory among Carnivorous Arthropods?', Ecology, vol. 84, no. 10, hal. 2522-2531

Eisikowitch, D \& Woodell, SR, 1975, 'Some Aspects of Pollination Ecology of Armeria maritima (Mill.) Willd. in Britain', The New Phytologist, vol. 74 , no. 2, hal. 307-322

Fleming, TH \& Kress, WJ, 2013, The Ornaments of Life: Coevolution and Conservation in The Tropic, University of Chicago Press, Chicago

Frouz, J \& Jilková, V, 2008, 'The Effect of Ants on Soil Properties and Processes (Hymenoptera: Formicidae)', Myrmecological News, vol. 11, no. 11, hal. 191-199

García-Martínez, M, Martínez-Tlapa, DL, PérezToledo, GR, Quiroz-Robledo, LN, CastañoMeneses, G, Laborde, J \& ValenzuelaGonzález, JE, 2015, 'Taxonomic, Species and Functional Group Diversity of Ants in a Tropical Anthropogenic Landscape', Tropical Conservation Science, vol. 8, no. 4, hal. 1017-1032

Gotelli, NJ, Ellison, AM, Dunn, RR \& Sanders, NJ, 2010, 'Counting Ants (Hymenoptera: Formicidae): Biodiversity Sampling and Statistical Analysis for Myrmecologists', Myrmecological News, vol. 15, hal. 13-19

Gullan, P \& Cranston, P, 2010, The Insects: An Outline of Entomology, Wiley-Blackwell, New Jersey

Hadi, S, 2004, Metodologi Research, Andi Offset, Yogyakarta 
Haneda, NH, C. Kusmana, FDK, 2013, 'Keanekaragaman Serangga di Ekosistem Mangrove', Jurnal Silvikultur Tropika, vol. 4, no. 1, hal. 42-47

Hashimoto, Yoshiaki \& Rahman, 2003, Inventory \& Collection: Total Protocol for Understanding of Biodiversity, Sabah

Heatwole, H \& Muir, R, 1989, 'Seasonal and Daily Activity of Ants in the Pre-Saharan Steppe of Tunisia', Journal of Arid Environments, vol. 16, no. 1, hal. 49-67

Herbers, JM \& Choiniere, E, 1996, 'Foraging Behaviour and Colony Structure in Ants', Animal Behaviour, vol. 51, no. 1, hal. 141-153

Heterick, BE, 2003, 'Two New Australian Monomorium Mayr (Hymenoptera: Formicidae), Including a Highly Distinctive Species', Australian Journal of Entomology, vol. 42, no. 3 , hal. 249-253

Heterick, BE \& Shattuck, S, 2011, 'Revision of the Ant Genus Iridomyrmex (Hymenoptera: Formicidae)', Zootaxa, vol. 2845, no. 4, hal. 1-174

Hölldobler, B \& Wilson, E, 1998, The Ants, Springer Berlin Heidelberg, Cambridge

Hosoishi, S \& Ogata, K, 2009, 'A Taxonomic Revision of the Asian Endemic Subgenus Physocrema of the Genus Crematogaster (Hymenoptera: Formicidae)', Zootaxa, vol. 36, no. 2062, hal. $15-36$

Hosoishi, S \& Ogata, K, 2016, 'Systematics and Biogeography of the Ant Genus Crematogaster Lund Subgenus Orthocrema Santschi in Asia (Hymenoptera: Formicidae)', Zoological Journal of the Linnean Society, vol. 176, no. 3, hal. 547-606

Hunter, MD, 2009, 'Trophic Promiscuity, Intraguild Predation and the Problem of Omnivores', Agricultural and Forest Entomology, vol. 11, no. 2, hal. 125-131

Hurlbert, AH, Ballantyne IV, F \& Powell, S, 2008, 'Shaking a Leg and Hot to Trot: The Effects of Body Size and Temperature on Running Speed in Ants', Ecological Entomology, vol. 33, no. 1, hal. 144-154

Jumar, 2000, Entomologi Pertanian, Rineka Cipta, Jakarta

Kost, C, Tremmel, M \& Wirth, R, 2011, 'Do Leaf Cutting Ants Cut Undetected? Testing the Effect of Ant-Induced Plant Defences on Foraging Decisions in Atta colombica', PLoS $O N E$, vol. 6 , no. 7 , hal. $1-8$

LaPolla, JS \& Fisher, BL, 2014, 'Then There were Five: A Reexamination of the Ant Genus Paratrechina (Hymenoptera, Formicidae), ZooKeys, vol. 48, no. 422, hal. 35-48
Longino, JT \& Colwell, RK, 1997, 'Biodiversity Assessment Using Structured Inventory: Capturing the Ant Fauna of a Tropical Rain Forest', Ecological Applications, vol. 7, no. 4, hal. 1263-1277

North, R, 1991, 'Transpiration and Humidity Preference in a Temperate Wood Ant Formica rufa L.', Journal of Insect Physiology, vol. 37, no. 4, hal. 279-286

Potts, L, Francke, O \& Cokendolpher, J, 1984, 'Humidity Preference of Four Species of Fire Ants (Hymenoptera: Formicidae: Solenopsis)', Insecte Sociaux, vol. 31, no. 3, hal. 335-339

Raynaldo, A, Rafdinal \& Linda, R, 2018, 'Kerapatan dan Biomassa Pohon di Kampus Universitas Tanjungpura sebagai Kantong Karbon Kota Pontianak', Protobiont, vol. 7, no. 1, hal. 6-12

Schaal, S, 2012, 'Messel' in eLS, John Wiley \& Sons, New Jersey.

Schultz, T, 2000, 'In Search of Ant Ancestors' Proceedings of the National Academy of Sciences of the United States of America, vol. 97, no. 26, hal. 14028-14029

Soepadmo, E \& Wong, K, 1995, Tree Flora of Sabah and Sarawak: Guide to Preparing and Editing Manuscripts, Print Resource Sdn. Bhd., Sabah

Ward, PS, 2007, 'Phylogeny, Classification, and Species-level Taxonomy of Ants (Hymenoptera: Formicidae)', Zootaxa, vol. 563, hal. 549-563

$\mathrm{Xu}, \mathrm{Z}-\mathrm{H}, 2001$, 'Two New Species of the Ant Genus Dolichoderus lund from Yunan, China', Acta Zootaxonomica Sinica, vol. 26, no. 3, hal. 355360

Xu, Z-H \& Zhou, X, 2015, 'Species Grouping and Key to Known Species of the Ant Genus Echinopla Smith (Hymenoptera: Formicidae) with Reports of Chinese Species', Asian Myrmecology, vol. 7, no. 1, hal. 19-36 